\title{
Activity of mushrooms against diabetic and inflammation: A review
}

\author{
Lena Ahmed Saleh Al-Faqeeh ${ }^{1,}{ }^{*}$, Rafiuddin Naser ${ }^{2}$, Kagne SR ${ }^{3}$ and Subur W. Khan ${ }^{4}$
}

${ }^{1}$ Research Scholar in Microbiology, Department of Botany, Maulana Azad College of Arts, Science and Commerce, Dr. Rafiq Zakaria Campus, Rauza Bagh, Aurangabad, M.S., 431001, India.

${ }^{2}$ Head Department of Botany, Maulana Azad College of Arts, Science and Commerce, Dr. Rafiq Zakaria Campus, Rauza Bagh, Aurangabad, M.S., 431001, India.

${ }^{3}$ Associate Professor of Microbiology, Department of Microbiology, Badrinarayan Barwale Mahavidyalaya College, Jalna. M.S., 431001, India.

${ }^{4}$ Department of Pharmacognosy, Y.B. Chavan College of Pharmacy, Dr. Rafiq Zakaria Campus, Aurangabad, M.S., 431001, India.

GSC Biological and Pharmaceutical Sciences, 2021, 14(02), 037-044

Publication history: Received on 23 January 2021; revised on 02 Februay 2021; accepted on 04 Februay 2021

Article DOI: https://doi.org/10.30574/gscbps.2021.14.2.0035

\begin{abstract}
Since ancient people, mushroom have been used as a source of food and in therapeutic remedies. Many recent studies confirm different biological activities of mushrooms which include antioxidant, antimicrobial, anticancer, antidiabetic and anti-inflammatory activities.

Many mushroom species have been evaluated for their antidiabetic and anti-inflammatory activities. This study highlights the effectiveness of mushrooms as antidiabetic and anti-inflammatory agents.
\end{abstract}

Keywords: Inflammation; Diabetic; Mushrooms; Active compounds; Anti-inflammation; Antidiabetic

\section{Introduction}

\subsection{Diabetes}

Diabetes mellitus its a group of metabolic diseases characterized by hyperglycemia, in which level of blood sugar elevated either because body cells do not respond properly to the insulin produced (insulin dysfunction) or the pancreas do not produce enough insulin (lack of insulin). Its a common health problem around the world and it have been estimated that by 2045 the number of diabetic patients could reach 629 million [1, 2].

\subsection{Diabetes mellitus classification}

Diabetes mellitus is classified as: type I diabetes, type II diabetes, gestational and other specific types of diabetes mellitus [3].

In type I diabetes mellitus, there is an absolute deficiency of insulin secretion due to the autoimmune destruction of beta pancreatic cells that lead to metabolic disturbances, especially affecting glucose homeostasis [4]. In type II diabetes mellitus, some mechanisms get damaged which regulate the cell sensitivity to insulin that ultimately leads to insufficient insulin secretion by the pancreatic beta cells, insulin dysfunction, and delayed insulin secretion through insulin resistance $[5,6]$. In gestational diabetes mellitus, diabetes mellitus arises during second or third trimester of pregnancy.

\footnotetext{
${ }^{*}$ Corresponding author: Lena Ahmed Saleh Al-Faqeeh

Maulana Azad Collage of Arts, Science and Commerce, Dr. Rafiq Zakaria Campus, Rauza Bagh, Aurangabad, M.S. 431001, India. 
The women about $20-50 \%$ are affected with this type. Insufficient insulin production during pregnancy to meet the extra needs leads to gestational diabetes [7]. In Other specific types of diabetes mellitus, maturity onset diabetes of the young (MODY) is a non-insulin dependent diabetes. Studies show that $1 \%$ to $2 \%$ of diabetes cases diabetic patients about have this diabetic type [8].

\subsection{Symptoms of diabetes mellitus}

Symptoms of diabetes mellitus include weight loss, polyuria, blurring of vision and thrust [9]. The effects of diabetes mellitus include long-term complications like cardiovascular diseases, nephropathy that may be lead to renal failure, or neuropathy with risk of foot ulcers, amputation, charcot joints, sexual dysfunction, cancer and stroke [10- 13].

\subsection{Treatment of diabetes mellitus}

Exogenous insulin is required for the treatment of diabetes mellitus type I [14]. Several drugs are currently used in the treatment of diabetes mellitus type II, which include various oral antidiabetic agents such as biguanides, sulfonylureas, tolbutamide, glinides, $\alpha$-glucosidase inhibitors, thiazolidinediones, phenformin, troglitazone, repaglinide and rosiglitazone $[15,16]$. Although, these drugs have a side effect on patients and may probably increase the incidence of acute hepatitis, hepatic injury and renal tumors $[17,19]$.

Besides conventional oral and injectable medications, diabetes treatments include changing of lifestyle, diet modification, weight regulation, regular exercising and using of alternatives therapies such as herbal therapy [20-22].

Recently, researchers focused on the development of new drugs that are free from adverse effects such as nausea, diarrhoea, liver problems, and weight gain [23]. They are working on an alternative therapeutic approach to combat diabetes mellitus. Many studies aimed to decreasing postprandial hyperglycemia by delaying the absorption of carbohydrates/glucose through inhibition of $\alpha$-amylase, $\alpha$-glucosidase and carbohydrate hydrolysing enzymes using natural sources such as extracts from various species of plants and fungi [24].

\subsection{Antidiabetic activity of mushrooms}

Edible and medicinal mushrooms are functional foods which contain a variety of biologically active compounds with anti-diabetic effects. Numerous mushroom species appear to be effective in controlling of blood glucose levels and the modification of the course of diabetic complications. Both edible and medicinal mushrooms are ideal low calorie foods for diabetic patients since they contain low levels of carbohydrates, very low amounts of fats and cholesterol, high content of proteins, polysaccharides, lipids, vitamins and minerals, as well as a number of low molecular weight metabolites such as lectins, phenolic, alkaloids, sterols, terpenoids, and lactones substances [25- 28].

Mushrooms are known to contain compounds which help in proper functioning of the liver [29], pancreas and other endocrinal glands, thereby promoting formation of insulin and related hormones which ensure healthy metabolic functioning [30- 32]. Polysaccharides, such as beta glucans contained in mushrooms have the ability to restore the function of pancreatic tissues by causing increased insulin output by $\beta$ - cells, which leads to lowering of blood glucose levels. It has also been shown to improve the sensitivity of peripheral tissues to insulin. Consumption of mushrooms markedly decreases the lipid levels including total cholesterol, total triglyceride, and low-density lipoproteins; and increases the level of high-density lipoproteins [33].

Many studies indicated antidiabetic activity of mushrooms. Mycelial extract of Pleurotus ostreatus was noticed to reduce the serum glucose level in streptozotocin-induced diabetes mellitus in rats [34]. Ganoderma lucidum ethanol extract of powdered fruiting bodies reduce serum glucose in white rats [35]. Also, water and 80\% ethanol extracts of fruiting bodies of Ganoderma lucidum decreased glucose level in serum of streptozotocin-induced diabetic rats [36].

Also, Pleurotus florida methanolic extract showed a significant antidiabetic activity in rats which suggest its potential pharmacological activity to control diabetics and prevent it [37]. 70\% ethanol extracts of Hericium erinaceus, Tremella fuciformis, Ganoderma lucidum, Auricularia auriculajudae, Lentinus edodes, Grifola frondosa, Russula sanguinea and Agrocybe aegerita were investigated for their antidiabetic activity. Among all mushrooms Ganoderma lucidum express a significant antidiabetic activity [38].

In this connection, four antidiabetic-related proteins which are glyceraldehyde-3-phosphate dehydrogenase-like protein, catalase-like protein, profilin-like protein and trehalose phosphorylase-like (TP-like) protein which have high potential in lowering blood glucose level, reducing insulin resistance and vascular complications were extracted from Pleurotus pulmonarius [39]. Ethanolic extract of fruiting bodies of Astraeus hygometricus showed a significant reduced 
levels of blood glucose and better tolerance to glucose in alloxan induced diabetic mice [40]. Aqueous extract of fruiting bodies and mycelial biomass of Phellinus Badius showed a significant reduction in blood glucose in alloxan-induced diabetic rats [41]. Also, Mushrooms such as Phellinus linteus, Ganoderma lucidum, Agaricus bisporus, Agaricus subrufescens, Cordyceps sinensis, Pleurotus spp, Sparassis crispa, Inonotus obliquus, Poria cocos and Coprinus comatus have been reported to have anti-hyperglycemic effects and hypoglycemic effects (reduction of glucose levels in blood) [25].

Clinical trials of mushroom extracts effects were also reported. Dietary supplementation with fruiting bodies of Agaricus sylvaticus shows a significant reduction of fasting plasma glucose on 56 patients with colorectal cancer [42, 43]. Also, dietary supplementation with powdered fruiting bodies of Pleurotus ostreatus on 120 patients with type II diabetes showed significant association between mushroom supplementation and gradual reduction in hyperglycemia in type II diabetic patients [44].

\section{Inflammation}

Inflammation is a normal protective response to tissue injury which involves enzyme activation, cell migration, mediator release, tissue breakdown, tissue repair and fluid extravasations [45]. Its frequently associated with fever, swelling, pain and involves the increase in vascular permeability, increase of protein denaturation, plasma extravasation, vasodilation, and membrane alterations [46]. Inflammation is a physiologic defense mechanism that helps the body to protect itself against poisonous chemicals, infection, burn, allergens, or other noxious stimuli. Inflammations are mainly as acute and chronic inflammations [47]. While the initial intention of an inflammatory event is to support the human body, a prolonged and excessive inflammation is correlated with various clinical presentations like cardiovascular complications, arthritis and tumor progression (Fig. 1) [48- 51]. The present non-steroidal antiinflammatory drugs (NSAIDS) are commonly used to treat inflammation, but their long-term use causes severe side effects such as gastrointestinal bleeding, peptic ulcers and other effects such as hypersensitivity reactions [48, 52, 53]. For this reason, searching for alternative medicines, especially natural products that are more safer options to treat inflammation become necessary and beneficial [48]. Plants and mushrooms have been targeted, screened and identified as sources to treat inflammation [54-56].

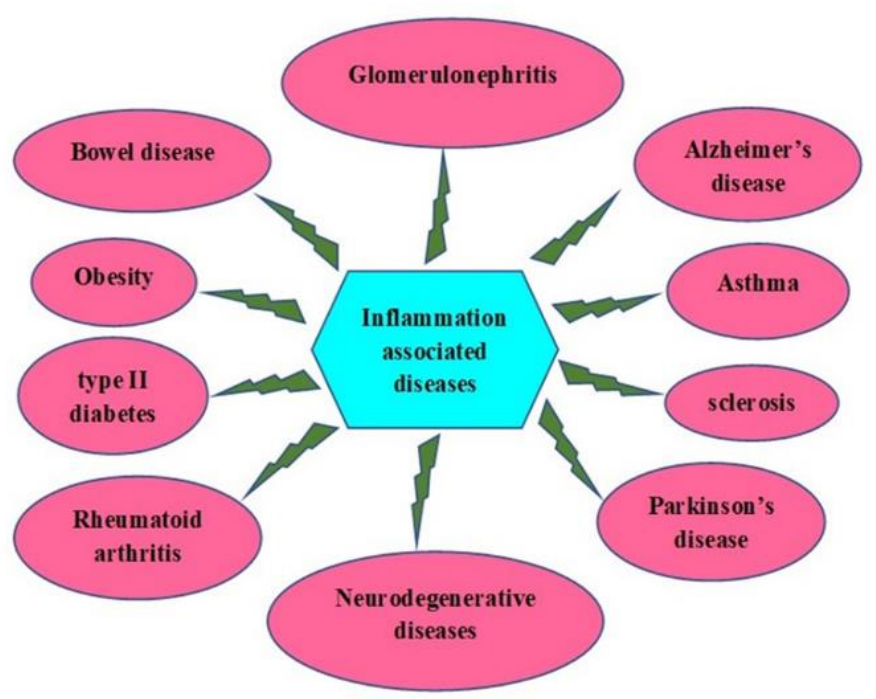

Figure 1 Inflammation associated diseases

\subsection{Anti-inflammatory activity of mushrooms}

Many previous studies have reported the bioactive compounds found in mushrooms exhibit significant antiinflammatory properties (Table 1). Anti-inflammatory activity of metabolite compounds, cordycepin, from Cordyceps species have been reported [57-60]. Cultured mycelia and fruiting bodies of Cordyceps militaris ethanolic extracts were reported to have an anti-inflammatory effect [60]. Also, anti-inflammatory effect against nociception and peritonitis in mice using an alkaline extract of Cordyceps militaris was reported [61]. Another compound, Adenosine, present in Cordyceps species showed an anti-inflammatory property by preventing tissue damage [58, 62- 64]. 
Table 1 Some anti-inflammatory compounds from mushrooms.

\begin{tabular}{|l|l|l|l|l|}
\hline Mushroom & Extract & Active compounds & Study model & References \\
\hline Tylopilus ballouii & Methanolic & $\begin{array}{l}\text { Galactomannan and non- } \\
\text { sulphated polysaccharide }\end{array}$ & Paw edema in mice & {$[65]$} \\
\hline Trametes orientalis & Ethanolic & Polysaccharides & Lewis lung carcinoma & {$[66]$} \\
\hline Ganoderma lucidum & Aqueous & $\beta$-D-glucan & Lewis lung carcinoma & {$[67]$} \\
\hline Pleurotus sajor-caju & Chloroform-methanol & $\beta$-D-glucan & $\begin{array}{l}\text { Peritonitis in Swiss } \\
\text { mice induced by } \\
\text { bacterial } \\
\text { lipopolysaccharide } \\
\text { (LPS) }\end{array}$ & $\begin{array}{l}\text { Nociception induced } \\
\text { by formalin in mice }\end{array}$ \\
\hline Cordyceps militaris & Aqueous & $\beta$-D-glucan & $\begin{array}{l}\text { Ischemic stroke model } \\
\text { in mice }\end{array}$ & {$[70]$} \\
\hline Hericium erinaceus & Ethanolic & $\begin{array}{l}\text { Erinacin and its derivative } \\
\text { Erinacin A }\end{array}$ \\
\hline
\end{tabular}

Culinary mushroom Pleurotus ostreatus freeze-dried powdered and acetone extracts have promising activity against inflammation induced in carrageenan-induced rat paw oedema model [54]. Anti-inflammatory effect of hydroalcoholic extracts of Ganoderma lucidum strains DARL-4 and MS-1were reported [71]. Ethanol extract of Agaricus bisporus fruiting bodies showed anti-inflammatory activity [72]. Ethyl acetate and petroleum ether extracts of Inonotus obliquus fruiting bodies reported to have anti-inflammatory effect [73].

In a study, water and ethanol extracts of fruiting bodies of Lactarius rufus showed a potent anti-inflammatory activity [74]. Pleurotus pulmonarius water and ethanol extracts demonstrated activity against inflammation [75]. Agaricus blazei whole mushroom chloroform extract and Agaricus bisporus whole mushroom methanol extract reported to have antiinflammatory property [76, 77]. Agaricus blazei powder in the form of capsules showed anti-inflammatory effect on Paw edema in rats [78]. Anti-inflammatory activity of ethanol and methanol extracts of Elaphomyces granulatus and Caripia montagnei were documented $[79,80]$.

\section{Conclusion}

This review documented different extracts and active compounds from mushrooms and the using of this extracts/ compounds as antidiabetic and anti-inflammatory compounds.

\section{Compliance with ethical standards}

\section{Disclosure of conflict of interest}

All authors disclose that they have no conflict of interest.

\section{References}

[1] Zheng Y, Bai L, Zhou Y, Tong R., Zeng M, Li X, et al. Polysaccharides from Chinese herbal medicine for anti-diabetes recent advances. Int J Biol Macromol. 2019; 121: 1240- 1253.

[2] Ganesan K, Chung SK, Vanamala J, Xu B. Causal relationship between diet-induced gut microbiota changes and diabetes: A novel strategy to transplant Faecalibacterium prausnitzii in preventing diabetes. Int J Mol Sci. 2018; 19(3720): 1-28.

[3] Ndisang JF, Jadhav A. The heme oxygenase system attenuates pancreatic lesions and improves insulin sensitivity and glucose metabolism in deoxycorticosterone acetate hypertension. Am J Physiol Regul Integr Comp. 2009; 98 : 211-223. 
[4] Ozougwu JC, Obimba KC, Belonwu CD, Unakalamba CB. The pathogenesis and pathophysiology of type 1 and type 2 diabetes mellitus. J Physiol Pathophysiol. 2013; 4: 46-57.

[5] Harris MI, Zimmet P. Classification of Diabetes Mellitus and Other Categories of glucose intolerance. In Albertik K,DeFronzo RA, Keen H, Zimmet P (Eds.). International Textbook of Diabetes Mellitus. John Wiley \& Sons. 1997; 3-18.

[6] Defronzo RA. The triumvirate: beta cell, muscle, liver. A collusion responsible for NIDDM. Diabetes. 1988; 37: 667-687.

[7] Spitaler MM, Graier WF. Vascular targets of redox signaling in diabetes mellitus. Diabetologia. 2012; 45: $476-494$.

[8] Katarea C, Saxena S, Agrawal S, Prasad GBKS. Alleviation of diabetes induced dyslipidemia by Lagenaria siceraria fruit extract in human type 2 diabetes. J Herb Med. 2013; 3: 1-8.

[9] Li WL, Zheng HC, Bukuru J, Kimpe ND. Natural medicines used in the traditional Chinese medical system for therapy of diabetes mellitus. J Ethnopharmacol. 2004; 92: 1-21.

[10] Warraich HJ, Rana JS. Diabetic dyslipidemia: epidemiology and prevention of cardiovascular disease and implications of newer therapies. Curr Cardiol Rep. 2018; 20(12): 125.

[11] Keerthana G, Kalaivani MK, Sumathy A. In-vitro alpha amylase inhibitory and anti-oxidant activities of ethanolic leaf extract of Croton bonplandianum. Asian J Pharm Clin Res. 2013; 6(4): 32-36.

[12] Ravi B, Renitta RE, Prabha ML, Issac, R, Naidu S. Evaluation of Antidiabetic Potential of Oyster Mushroom (Pleurotus ostreatus) in Alloxan-Induced Diabetic Mice. Immunopharmacol Immunotoxicol. 2013; 35(1): 101109.

[13] Intekhab A, Barry G. Diabetes mellitus. Clin Dermatol. 2006; 24: 237- 246.

[14] Puri KM, Prabhu PS, Dev G, Agarwal S, Murthy PS. Mechanism of antidiabetic action of compound GII purified from fenugreek (Trigonella foenum graecum) seeds. Indian J Clin Biochem. 2011; 26(4): 335-346.

[15] Mishra SB, Vijayakumar M, Ojha SK, Verma A. Antidiabetic effect of Jatropha curcas L. leaves extract in normal and alloxan-induced diabetic rats. Int J Pharm Sci Rev Res. 2010; 2: 482-87.

[16] Milani E, Nikfar S, Khorasani R, Zamani MJ, Abdollahi M. Reduction of diabetes-induced oxidative stress by phosphodiestrase inhibitors in rats. Comp Biochem Physiol C Toxicol Pharmacol. 2005; 140: 251-255.

[17] Khan RMM, Chua ZJY, Tan JC, Yang Y, Liao Z, Zhao Y. From pre-diabetes to diabetes: Diagnosis, treatments and translational research. Medicina. 2019; 55(9): 546.

[18] Gloyn AL, Drucker DJ. Precision medicine in the management of type 2 diabetes. Lancet Diabetes Endocrinol. 2018; 6: 891- 900 .

[19] Singh SK, Rai PK, Jaiswal D, Watal G. Evidence-based critical evaluation of glycemic potential of Cynodon dactylon. Evid Based Complement Alternat Med. 2007; 5 (4): 415- 420.

[20] Bharti SK, Krishnan S, Gupta AK. Herbal formulation to combat type 2 diabetes mellitus. Germany: LAMBERT Academic Publishing. 2013.

[21] Rafiuddin N. Plants known as antidiabetics from Aurangabad district- Maharashtra. Ann Pharm \&Pharm Sci. 2010; 1(2): 85-87.

[22] Hui H, Tang G, Go VL. Hypoglycemic herbs and their action mechanisms. Chin Med. 2009; 12: 4-11.

[23] Malviya N, Jain S, Malviya S. Antidiabetic potential of medicinal plants. Acta Pol Pharm. 2010; 67(2): $113-118$.

[24] Etxeberria U, de La Garza AL, Campin J, Martnez JA, Milagro, F.I. Antidiabetic effects of natural plant extracts via inhibition of carbohydrate hydrolysis enzymes with emphasis on pancreatic alpha amylase. Expert Opin Ther Targets. 2012; 16(3): 269- 297.

[25] Silva DD, Rapior S, Hyde KD, Bahkali AH. Medicinal mushrooms in prevention and control of diabetes mellitus. Fungal Divers. 2012; 56:1- 29.

[26] Teng BS, Wang CD, Zhang D, Wu JS, Pan D, Pan LF, et al. Hypoglycemic effect and mechanism of a proteoglycan from Ganoderma lucidum on streptozotocin-induced type 2 diabetic rats. Eur Rev Med Pharmacol Sci. 2012; 16: 166- 175. 
[27] Cui B, Han L, Qu J, Lv Y. Hypoglycemic activity of Grifola frondosa rich in vanadium. Biol Trace Elem Res. 2009; 131(2): 186-191.

[28] Konno S, Aynehchi S, Dolin DJ, Schwartz AM, Choudhury MS,Tazaki H. Anticancer and Hypoglycemic Effects of Polysaccharides in Edible and Medicinal Maitake Mushroom [Grifola frondosa (Dicks.: Fr.) S. F. Gray]. Int J Med Mushrooms. 2002; 4(3): 131-142.

[29] Wani BA, Bodha RH, Wani AH. Nutritional and medicinal importance of mushrooms. J Med Plants Res. 2010; 4: 2598- 2604.

[30] Chen J, Mao D, Yong Y, Li J, Wei H, Lu L. Hepatoprotective and hypolipidemic effects of water-soluble polysaccharidic extract of Pleurotus eryngii. Food Chemistry. 2012; 130(3): 687- 694.

[31] Zhang HN, Lin ZB. Hypoglycemic effect of Ganoderma lucidum polysaccharides. Acta Pharmaceutica Sinica. 2004; 25: 191- 195.

[32] Wasser SP, Weis AL. Medicinal properties of substances occurring in higher Basidiomycetes mushrooms: current perspectives (review). Int J Med Mushrooms. 1999; 1: 31- 62.

[33] Lee KH, Morris-Natschke SL, Yang X, Huang R, Zhou T, Wu SF, et al. Recent progress of research on medicinal mushrooms, foods, and other herbal products used in traditional Chinese medicine. J Tradit Complement Med. 2012; 2(2): 84- 95.

[34] Sangi ASM, Bawadekji A, Al-Ali M. Comparative effects of metformin, Pleurotus ostreatus, Nigella sativa and Zingiber officinale on the streptozotocin-induced diabetes mellitus in rats. Pharmacogn Mag. 2018; 14: S268S273.

[35] Ratnaningtyas NI, Hernayanti H, Andarwanti S, Ekowati N, Purwanti ES, Sukmawati D. Effects of Ganoderma lucidum extract on diabetic rats. Biosaintifika: J Bio \& Bio Edu. 2018; 10: 642- 647.

[36] Bach E, Hi E, Martins A, Nascimento P, Wadt N. Hypoglicemic and hypolipedimic effects of Ganoderma lucidum in streptozotocin-induced diabetic rats. Medicines. 2018; 5(3): 78.

[37] Prabu M, Kumuthakalavalli R. Antidiabetic potential of the oyster mushroom Pleurotus florida (mont.) singer. Int J Curr Pharm Res. 2017; 9(4): 51-54.

[38] Tong Wu, Baojun Xu. Antidiabetic and Antioxidant Activities of Eight Medicinal Mushroom Species from China. Int J Med Mushrooms. 2015; 17(2): 129- 140.

[39] Wahab NAA, Abdullah N, Aminudin N. Characterisation of Potential Antidiabetic-Related Proteins from Pleurotus pulmonarius (Fr.) Quél. (Grey Oyster Mushroom) by MALDI-TOF/TOF Mass Spectrometry. Biomed Res Int. 2014; 1-9.

[40] Biswas G, Acharya K. Hypoglycemic activity of ethanolic extract of Astraeus hygometricus (Pers.) Morg. in alloxan induced diabetic mice. Int J Pharm Pharm Sci. 2013; 5(1): 391-394.

[41] Sonawane HB, Ghole VS, Garad S. Hypoglycemic Effect of Phansomba (Phellinus Badius Berk Ex Cooke) G. Cunn. on Alloxan-induced Diabetic Rats. J Nat Remedies. 2013; 13(1): 29- 34.

[42] Fortes RC, Novaes MR, Recôva VL, Melo AL. Immunological, hematological, and glycemia effects of dietary supplementation with Agaricus sylvaticus on patients' colorectal cancer. Exp Biol Med. 2009; 234: 53- 62.

[43] Fortes RC, Recôva VL, Melo AL, Novaes MRCG. Effects of dietary supplementation with medicinal fungus in fasting glycemia levels of patients with colorectal cancer: a randomized, double-blind, placebo-controlled clinical study. Nutr Hosp. 2008; 23: 591- 598.

[44] Agrawal RP, Chopra A, Lavekar GS, Padhi MM, Srikanth N, Ota S, et al. Effect of oyster mushroom on glycemia, lipid profile and quality of life in type 2 diabetic patients. Aust J Medical Herbal. 2010; 22(2): $50-54$.

[45] Vane JR, Botting RM. New insights into the mode of action of anti-inflammatory drugs. Inflamm Res. 1995; 44: 110.

[46] Umapathy E, Ndebia EJ, Meeme A, Adam B, Menziura P, Nkeh-Chungag BN, et al. An experimental evaluation of Albuca setosa aqueous extract on membrane stabilization, protein denaturation and white blood cell migration during acute inflammation. J. Med. Plants Res. 2010; 4: 789-95.

[47] Hossain M, Chowdhury M, Das S, Chowdhury I. In vitro thrombolytic and anti-inflammatory activity of Swertia chirata ethanolic extract. J Pharmacogn Phytochem. 2012; 1: 99-104. 
[48] Taofiq O, Martins A, Barreiro MF, Ferreira IC. Anti-inflammatory potential of mushroom extracts and isolated metabolites. Trends Food Sci Technol. 2016; 50: 193- 210.

[49] Garrett WS, Gordon JI, Glimcher LH. Homeostasis and inflammation in the intestine. Cell. 2010; $140(6): 859-870$.

[50] Glass CK, Saijo K, Winner B, Marchetto MC, Gage FH. Mechanisms underlying inflammation in neurodegeneration. Cell. 2010; 140(6): 918- 934.

[51] Fakhouri F, Frémeaux-Bacchi V, Noël LH, Cook HT, Pickering MC C3 glomerulopathy: a new classification. Nat Rev Nephrol. 2010; 6(8): 494- 499.

[52] Sevinsky R, Stewart D, Harirforoosh S. Nonsteroidal anti-inflammatory drugs: Is there a link between cardiovascular and renal adverse effects?. J Integr Nephrol Androl. 2017; 4: 1 - 2.

[53] Rang HP, Dale MM, Ritter JM, Flower RJ, Henderson G. Rang and Dale's Pharmacology. 7th ed.,. London, UK: Churchill Livingstone. 2012.

[54] Banukie WJANJ, Handunnetti SM, Wanigatunge CA, Fernando GH, Abeytunga DTU, Suresh TS. Anti-Inflammatory Activity of Pleurotus ostreatus, a Culinary Medicinal Mushroom, in Wistar Rats. Evid Based Complement Alternat Med. 2020; 1-9.

[55] Sajon SR, Sana S, Rana S, Rahman SMM, Nishi ZM. Mushrooms: Natural factory of anti-oxidant, anti-inflammatory, analgesic and nutrition. J Pharmacogn Phytochem. 2018; 7(1): 464- 475.

[56] Oguntibeju 00. Medicinal plants with anti-inflammatory activities from selected countries and regions of Africa. J Inflamm Res. 2018; 11: 307- 317.

[57] Yang ML, Kuo PC, Hwang TL, Wu TS. Anti-inflammatory principles from Cordyceps sinensis. J Nat Prod. 2011; 74: 1996- 2000.

[58] Tsai YJ, Lin LC, Tsai TH. Pharmacokinetics of adenosine and cordycepin, a bioactive constituent of Cordyceps sinensis in rat. J Agric Food Chem. 2010; 58: 4638- 4643.

[59] Kim SJ, Kim MC, Lee BJ, Park DH, Hong SH, Um JY. Anti-Inflammatory activity of chrysophanol through the suppression of NF-kappaB/caspase-1 activation in vitro and in vivo. Molecules. 2010; 15: 6436-6451.

[60] Won SU, Park EH. Anti-inflammatory and related pharmacological activities of cultured mycelia and fruiting bodies of Cordyceps militaris. J Ethnopharmacol. 2005; 96(3): 555-561.

[61] Shrestha B, Sang KH, Sung JM, Sung GH. Fruiting body formation of Cordyceps militaris from multi-ascospore isolates and their single ascospore progeny strains. Mycobiology. 2012; 40: 100- 106.

[62] Park SY, Jung SJ, Ha KC, Sin HS, Jang SH, Chae HJ, et al. Antiinflammatory effects of Cordyceps mycelium (Paecilomyces hepiali, CBG-CS-2) in raw 264.7 murine macrophages. Orient Pharm Exp Med. 2015; 15 : 7- 12.

[63] Liu Y, Wang J, Wang W, Zhang H, Zhang X, Han C. The chemical constituents and pharmacological actions of Cordyceps sinensis. Evid Based Complement Alternat Med. 2015; 1-12.

[64] Kim TW, Yoon DH, Cho JY, Sung GH. Anti-inflammatory compounds from Cordyceps bassiana (973.3). FASEB J. 2014; 28(1): 973-973.

[65] Lima AT, Santos MN, Souza LA, Pinheiro TS, Paiva AA, Dore CM, et al. Chemical characteristics of heteropolysaccharide from Tylopilus ballouii mushroom and its antioxidant and anti-inflammatory activities. Carbohydr Polym. 2016; 144: 400-409.

[66] Zheng Y, Wang WD, LI Y. Antitumor and immunomodulatory activity of polysaccharide isolated from Trametes orientalis. Carbohydr Polym. 2015; 131: 248- 254.

[67] Wang WJ, Wu YS, Chen S, Liu CF, Chen SN. Mushroom $\beta$-glucan may immunomodulate the tumor-associated macrophages in the Lewis lung carcinoma. Biomed Res Int. 2015; 1-15.

[68] Silveira ML, Smiderle FR, Moraes CP, Borato DG, Baggio CH, Ruthes AC, et al. Structural characterization and antiinflammatory activity of a linear $\beta$-D-glucan isolated from Pleurotus sajor-caju. Carbohydr Polym. 2014; 113: 588596.

[69] Smiderle FR, Baggio CH, Borato DG, Santana-Filho AP, Sassaki GL, Iacomini M, et al. Anti-Inflammatory properties of the medicinal mushroom cordyceps militaris might be related to its linear $(1 \rightarrow 3)-\beta$-D-Glucan. PLoS One. 2014; 9(10): 1-11. 
[70] Lee KF, Chen JH, Teng CC, Shen CH, Hsieh MC, Lu CC, et al. Protective effects of Hericium erinaceus mycelium and its isolated erinacine A against ischemia-injury-induced neuronal cell death via the inhibition of iNOS/p38 MAPK and nitrotyrosine. Int J Mol Sci. 2014; 15(9): 15073-15089.

[71] Swati A, Tiwari PS, Negi Meena HS. A Comparative evaluation of in vitro anti-inflammatory and antifungal activity of Ganoderma lucidum strains DARL-4 and MS-1. Int J Green Pharm. 2018; 12(1): S126- S130.

[72] Ruthes AC, Rattmann YD, Malquevicz-Paiva SM, Carbonero ER, Córdova MM, Baggioet CH, et al. Agaricus bisporus fucogalactan: structural characterization and pharmacological approaches. Carbohydr Polym. 2013; 92(1): 184191.

[73] Ma L, Chen H, Dong P, Lu X. Anti-inflammatory and anticancer activities of extracts and compounds from the mushroom Inonotus obliquus. Food Chem. 2013; 139(1-4): 503-508.

[74] Ruthes AC, Carbonero ER, C'ordova MM. Lactarius rufus $(1 \rightarrow 3),(1 \rightarrow 6)$ - -d-glucans: structure, antinociceptive and anti-inflammatory effects. Carbohydr Polym. 2103; 94(1): 129-136.

[75] Lavi I, Nimri L, Levinson D, Peri I, Hadar Y, Schwartz B. Glucans from the edible mushroom Pleurotus pulmonarius inhibit colitis-associated colon carcinogenesis in mice. J Gastroenterol. 2012; 47(5): 504-518.

[76] Song HH, Chae HS, Oh SR, Lee HK, Chin YW. Anti-inflammatory and anti-allergic effect of Agaricus blazei extract in bone marrow-derived mast cells. The American J Chin Med. 2012; 40(5): 1073-1084.

[77] Moro C, Palacios I, Lozano M, D’Arrigo M, Guillamón E, Villares A, et al. Anti-inflammatory activity of methanolic extracts from edible mushrooms in LPS activated RAW 264.7 macrophages. Food Chem. 2012; 130(2): 350 - 355.

[78] Carvalho CD, Alves NC, Monteiro AC, Pelógia NCC. Antinociceptive and anti-inflammatory effect of Agaricus blazei Murill in rats submitted to the modified formalin test. Revista Dor São Paulo. 2011; 12(1): 35-8.

[79] Wang S, Marcone MF. The biochemistry and biological properties of the world's most expensive underground edible mushroom: truffles. Food Res Int. 2011; 44(9): 2567-2581.

[80] Queiroz LS, Nascimento MS, Cruz AKM, Castro AJG, Moura MDEV, Baseia IG, et al. Glucans from the Caripia montagnei mushroom present anti-inflammatory activity. Int Immunopharmacol. 2010; 10(1): 34-42. 